\title{
Utopia: Marge Piercy as a Social Critic in Woman on the Edge of Time
}

\author{
Gassim H. Dohal ${ }^{1}$ \\ ${ }^{1}$ Associate Prof. of English, Al-Imam Muhammad Ibn Saud Islamic University, Riyadh, Saudi Arabia \\ Correspondence: Gassim H. Dohal, Associate Prof. of English, Al-Imam Muhammad Ibn Saud Islamic \\ University, Riyadh, Saudi Arabia. E-mail: dr_waitme@hotmail.com
}

Received: July 3, 2019 Accepted: July 31, 2019 Online Published: August 20, 2019

doi:10.5539/ells.v9n3p1 URL: https://doi.org/10.5539/ells.v9n3p1

\begin{abstract}
In her utopian novel Woman on the Edge of Time (1976), Marge Piercy critically addresses class, gender, and race as political and social issues in the contemporary society. These matters cause struggle and wars among social classes and individuals as well. People who suffer the effects of these problems struggle for survival and consider themselves in wars with their oppressors as Bee, one of Piercy's characters in the novel, states, "We're all at war" (Piercy, p. 328). Race, gender and class are related in sense that all of them bring suffering to people and are used by any social domineering authority to persecute and dominate those oppressed people. In the following pages, I will discuss the concepts of class, gender, and race, and how these issues are used in Piercy's masterpiece Woman on the Edge of Time to set light on some atrocities of her contemporary world, and at the same time, to provide a utopian future alternative she intentionally urges her readers to think about and if possible to work for.
\end{abstract}

Keywords: class, gender, race, utopia, future, Piercy

[Connie's] act is political. It affirms her individual revolt in a way that may help to bring about a future in which her descendants can affirm their humanity and their individuality. (Jones, p. 181)

What is the function of utopias in our contemporary life? This is the question a reader may raise after reading a utopian work like Marge Piercy's Woman on the Edge of Time (Fawcett Crest Ed., 1976). One of the main goals of utopias is to function as a political and social critique of existing societies. Such a critique focuses on revealing the flaws of real cultures and societies, and poses some alternatives and proposals for the reform of those defects. According to Fredric Jameson, "Utopias have something to do with failure and tell us more about our own limits and weaknesses than they do about perfect societies" (n. p.). At the same time, the critique assumes a warning against a bad, miserable future if the present society proceeds without correcting its deficiencies. In this context, Marge Piercy presents a political and social critique of her existing society through her utopian novel, Woman on the Edge of Time.

In order to present and critique values of the American twentieth-century society, Piercy chooses a Chicana woman who suffers the consequences of all class, gender, and race. Indeed, "Connie's discrimination takes place on three levels: that of gender, class and race, all of which constitute the grounds for her social oppression" (Makinen, p. 17) and readers should not forget "the determinants of power" in a patriarchal society (Bammer, p. 96). Furthermore, Frances Bartkowski points out, "Piercy chose Connie to narrate her own story because her life is one in which many of the social practices criticized by contemporary feminism are brought to light" (p. 53). Consuelo (Connie) Ramos is a poor, Mexican American female, living in New York. More than this, Piercy makes her heroine mad in order to bring light to how treatment is affected and indeed determined by the matters in question, i.e. class, gender, and race. Ultimately, the author manages "to embody the intersections of gender, class, race, and mental illness" (Thibodeau, p. 110). Connie's patriarchal society commits her "to a mental institution which is depicted as both a dystopia and microcosm of the broader society" (Wetzel, p. 54). One expects such an institution to help this poor female rather than to become a device in the hands of those who have power to curb and limit her abilities and choices in life. Actually, "the very beginning of the novel reveals that the present society is one of unquestionable masculine order in which women are deprived of any feelings" (Sümbül, p. 176) and rights. The State has taken away her daughter, killed her lover, and left her on welfare. She is already inferior because of her race, gender and class, so there is no need for using more power and violence against her. Yet, her society insists on more violence in order to keep her under control and apply its ideological beliefs regarding women's status in general and colored people in particular. 
In a patriarchal society like that of Connie, the irregular treatment of women, in general, springs in part from their peculiar social definition: whereas men have assigned functions to do, women's duties are derived from and related to their sexuality. While such a society thinks of sexuality as a negative characteristic that denotes the inferiority of women, Piercy propounds sexuality that is based on equality and respect in the utopian alternative of Mattapoisett of the year 2137 she establishes in the novel. Luciente, Connie's future society friend and alter ego, states, "We couple ... for love, for pleasure, for relief, out of habit, out of curiosity and lust" (Piercy, p. 64). In the novel, Piercy's heroine has two influential relations based on equality and respect.

Connie's first relation is with the blind, black Claud. She lives a good life with him though he is a pickpocket. When he is exposed to an abusing treatment, and dies, she finds it better to die and turns to drinking alcohol. Hence, his death causes a turning point in her life. The second relation is the one that she has with Bee of the future society of Mattapoisett Piercy invents to give her heroine access to communicate, express herself, and later on to justify what she will do in the mental hospital. This imagined relation reminds her of Claud, and gives her the sense of family again after losing everything in her actual society. Indeed, "Piercy, a long-time activist, strives to politicize her readers, as Connie's new friends encourage her to recognize her potential for resistance" (O'Byrne, p. 8). She starts to listen to Bee's advice when he tells her:

We're all at war. You're a prisoner of war. May you free yourself ... there's always a thing you can deny an oppressor if only your allegiance. Your belief. Your co-oping ... (Piercy, p. 328)

In this way, Bee gives her the confidence she has lost after Claud's death. This confidence creates in her a fighting-back spirit. Hence, she starts to think of a desperate act of retaliation. After she fails to escape from the hospital, she starts thinking of another way. Hence, "yes, she had stolen a weapon. War, she thought again. She would fight back" (Piercy, p. 363). At the end of the novel, Connie thinks, "At last once I fought and won" (Piercy 375). Sarah Lefanu argues, "At the beginning of the book Connie is a powerless victim, but by the end she has become an agent for the future" (p. 61) of Mattapoisett where "constructs of gender, race, sexuality, and mental health have been rendered obsolete" (Thibodeau, p. 116).

On the other hand, a patriarchal society classifies women according to their sexual relations with men. A woman's status in such a social system is closer to that of her man than to that of other women including patriarchy among colored people. Connie suffers for being a female; her husband, Eddie, beats her and leaves her at the end without a job or money though she is still his wife and carries his name Ramos according to the State records. He does so because she does not have "the money to divorce him for her desertion" (Piercy, p. 113). In the same context, Connie's niece, Dolly, in that patriarchal system chooses Geraldo over anybody else even her aunt, and her unborn baby. From the very beginning, the reader knows that Dolly's father "washes his hands of" her. Thus, she finds no way but that "he [Geraldo] is my man" (Piercy, p. 24). Her social duties are to do what her man wants her to do even if he wants her to lie. She becomes passive and helps in strengthening the present authoritarian system through her reliance on a man. When her husband accuses Connie of attacking him and her, Dolly just corroborates his claim. Hence, Dolly participates and accepts her destiny in the patriarchal system.

In her novel, Piercy wants to warn her audience and readers that supporting such a system will lead to a disaster in the future. After having had the dialytrode implanted in her brain, Connie time-travels by mistake to a dystopian world, which is an extension of Connie's current society. This future is the result of the kind of experiment in which Connie is involved. She transfers a horrible picture of that future when she meets Gildina, whose body

seemed a cartoon of femininity, with a tiny waist, enormous sharp breasts that stuck out ... Her stomach was flat but her hips and buttocks were oversized and audaciously curved. She looked as if she could hardly walk for the extravagance of her breasts and buttocks, her thighs that collided as she shuffled a few steps. (Piercy, p. 288)

Gildina as a future woman is no more than a commodity that is kept as long as it is valuable for its user. Gildina points out that "you can't get out of a contract unless you're bought out" (Piercy, p. 290). Women like Gildina are "monitored like everybody else" in that dystopian future, and "from the electrical impulses" in their brains, they "can't lie" (Piercy, p. 298). In fact, "in Connie's reality and in Gildina's future, the female identity is shaped (and sometimes condemned) by sexuality, motherhood, economic condition and race" (Minico, p. 10). Nowadays after forty something years from the writing of this masterpiece, programs and/or ads are full of those "cartoons of femininity" with "enormous breasts" and "oversized hips and buttocks?" (Piercy, p. 288)

Actually, Gildina is a more developed copy of Dolly who accepts and shares in the continuity of the patriarchal system. Connie may accept her destiny if she is left alone. But what happens to her is much: they have taken her daughter, killed her lover, and finally she is denied to have a small family with her niece and her children. 
Ultimately, "Connie has never had the chance to live the life she wanted to live" (Bakay, p. 332). Dolly is her hope to make a family because she cannot become pregnant anymore after becoming "no long a woman. An empty shell" (Piercy, p. 45). After an abortion, "unnecessarily they [doctors] had done a complete hysterectomy because the residents wanted practice ... and [she would] never again hope for a child" (Piercy, p. 45).

What happens to Connie is not new because the oppressed, in particular the colored people, are used for the purpose of experiments in her society at least according to what is mentioned in the novel. The oppressors have put Connie's sister, Inez, under experiments of birth-control pills. Such an experiment "actually happened in San Antonio in 1971" (Jones, p. 177). In Connie's world, the female body becomes a field of experimental science and abuse: abortion, hysterectomy, prostitution, chemical control and other inhumane practices. While talking about her sister to Luciente, Connie says,

They like to try out medicine on poor people. Especially brown people and black people. Inmates in prisons too. So ... you must test drugs on people too? You have to. (Piercy, p. 275)

From the above quotation, it is clear that racism is also practiced even in what seems to be humanitarian; i.e., medical institutions. This practice raises the question of medical ethics. Anne Hudson Jones explains this point as follows,

As long as that ethos includes the sexist and racist attitudes of the larger society, female and nonwhite male patients will be treated differently (less ethically) than the white male patients. (p. 172)

Moreover, race determines even the educational and social level in the eyes of people; Connie feels that she is inferior in front of others: "I had two years of college! Just because I'm a Chicana and on welfare, don't try to tell me what poor vocabulary I speak with" (Piercy, p. 42). She has no chance to pursue her education because her race determines the level and type of education she should have.

Indeed, race determines economics as well. On her part, Dolly, Connie's niece, submits to Geraldo in order to make a living. Though he makes her work as a prostitute, yet it seems that she is unable to find another job. Here she is used as a commodity. In this sense, Judith Spector argues, "Piercy's basic premise concerning sexuality is political: Women in our culture sell themselves, with or without a choice in the matter, to men who abuse them" (p. 203). Dolly tells her aunt, "Listen, every woman sells it" (Piercy, p. 39). Luciente comments on Dolly's profession, "Prostitution? I've read of this and seen a drama too about person who sold per body to feed per family!" (p. 64). She wonders while talking to Connie, "We couple. Not for money, not for a living. For love, for pleasure, for relief ..." (Piercy, p. 64). For a pimp like Geraldo, it is money that makes him keep Dolly. Hence, Dolly is wrong when she thinks "a man respects you more if you have his baby" (Piercy, p. 39). Apparently, her understanding of the manipulating and domineering society and how it works goes the wrong way.

Furthermore, economics plays a major role in Connie's life. In a capitalist society, it is money that makes a person important. From the beginning, the reader realizes that Connie lives on welfare. She has no enough money to buy what she wants. She depends on Claud, the pickpocket, who "brought home good things for her and her baby" (Piercy, p. 26). After his death, Connie's life becomes boring and hard because she is not able to find a job. Her life is best summarized early in the novel:

Usually a sensation of repetition upon waking was a waking to: again bills, again hunger, again pain, again loss, again trouble. Again, no Claud, again no Angelina, again the rent due, again no job, no hope. (Piercy, p. 33)

One living such a life should become mad, unstable, worried, and suffering. No hope is left. What kind of life could be after all this? What is left is to think of suicide or taking a desperate action. Connie desperately states, "If you [as a patient] complained, they [doctors and nurses] took it as a sign of sickness" (Piercy, p. 18). Hence, there is no hope left for her in this equivocal society, as Anne Hudson Jones puts it

As long as these women are treated by psychiatrists who themselves accept and act out the sexist culture, they have little hope of achieving complete selfhood or even, in many cases, of living outside mental institutions. (p. 172)

She has to accept the victim role or take an enigmatic action. And in both cases, she will miss a lot and face the consequences of her decision. For sure, she will end up indicted if she tries any desperate action.

At the beginning of the novel, Connie emerges as a powerless victim who finds a resort in visiting the future utopian society of Mattapoisett "where human potential is valued" (Afnan, p. 335) and where respect, equity, and equality prevail. When her niece comes to see her, she is time-traveling to the future. Such a travel gives her a mental and psychological exit to avoid her current problems. At the same time, it is a way of creation; she is 
creating a meaning for her life by being able to communicate with the future and by becoming part of that future. It is the future world that gives her confidence to take action at the end. Her society has destroyed her; nothing is left for her to sacrifice for. Because her niece is the last chance for her to "live together" (Piercy, p. 14) and have a sense of a family, she wants to defend her niece. Hence, she does not hesitate at the beginning of the novel to smash the nose of her niece's "man". Indeed, Piercy takes this normal action that might happen in any family as one of the reasons to present and subsequently to criticize the merciless society with its values. The man claims that she has attacked him and Dolly in Dolly's house. Because of her psychiatric history, Connie is taken to a supposedly humanitarian institution.

The doctors in the mental hospital she has been taken to do not need anything from Connie as a patient more than "her name and the date" (Piercy, p. 18). This behavior leads to a big problem; i.e., what about the patient's consent of taking any procedure? In this place, her rib is broken, but she cannot say anything because her complaint will be considered as a sign of her madness. She is locked in seclusion, and let to lie down on "the bare, piss-stained mattress" (Piercy, p. 79). What kind of treatment is this? It is indeed torture. By the way, one may enjoy reading American Notes by Charles Dickens who writes about the disreputable treatment of American medical centers in the 19th century.

On her part, Piercy definitely projects the suffering of poor people, particularly the colored, during their treatment in hospitals. The doctors and nurses are some sort of butchers who have no mercy. The problem is that "they have your records right there, so they know the answers [for their questions], or they think they do" (Piercy, p. 91). More than this, they "like to try out medicine on poor people. Especially brown people and black people" (Piercy, p. 275) as if these people are not human. The women, mostly "black and Puerto Rican" are treated to "obscene jokes" (Piercy, pp. 159-160). In the hospital, the doctors implant electrodes in the patients' brains in order to control their emotions. They want to create machines out of those poor patients, as Sybil, one of the patients, points out, "Control. To turn us into machines so we obey them" (Piercy, p. 200). Of course, if there is no action against this sabotage, the future will be that of Gildina where everyone is "monitored" (Piercy, p. 298). After having that sort of operations on her brain, Connie becomes "an object" (Piercy, p. 302). This is the last thing one can expect; making experiments on the patients without their consents. Bethan Tyler argues, "Perhaps the most striking example of Connie's lack of autonomy comes in a scene in which she is subjected to brain surgery, without consenting to it" (p. 59). Connie has to take the medicine, obey the doctors, and accept their decision without her consent. Moreover, doctors warn her,

Connie you are resisting. You are the patient. You know why you are here. The more you resist, the more you punish yourself. Because when you fight us, we can't help you. (Piercy, pp. 261-262)

One of the differences that she sees in the future utopian society she frequently visits is that no patient is put under pressure. Each one in that society is free to volunteer to experiments. Each member of that utopian future society is free and respectable, and "difference is not suppressed or punished but welcome" (Sümbül, p. 333).

In her patriarchal society, Connie cannot find freedom, and is denied her basic rights. Being able to time-travel in the future, she gains confidence, and gets advice. More than anything else, she finds a family. The future she voluntarily travels to is different in everything from her patriarchal, unjust, and merciless society. The future society seems to be the product of "women's long revolution" (Piercy, p. 105). As long as Connie is considered as a visitor from an ancient past, and this past has something to do with the women's revolution, and subsequently with the future, Luciente insists on Connie's participation in this past: "But try! You're important to us, we want you to survive and break out" (Piercy, p. 262). Bee, on his part, advises, "We're all at war" and "there's always a thing you can deny an oppressor" (Piercy, p. 328). Connie has to play her part because her action in the current tortuous society may create the type of future. This promising future society is one possibility that Connie's reaction against aggression and oppression at her time may lead to. Peter Seyferth writes about this idea:

[Connie] learns that the actuality of this future society depends on her own action in the present; if she does not fight now, the evils of contemporary society will grow even worse. (p. 3)

As a matter of fact, the future society may bring solutions to problems of Connie's contemporary society, particularly class, gender, and race. The imagined society does "enjoy no one culture, but many. Many arts" (Piercy, p. 178). Though this future celebrates diversity, yet this diversity does not lead to racism, as it is the case in Connie's society. In the future society, everyone is proud of his culture and at the same time respects other cultures. While talking about cultures, Connie refers to the political movement of the blacks, "in my time black people just discovered a pride in being black. My people, Chicanos, were beginning to feel that too" (Piercy, p. 103). As racism is eliminated in the future society, sexuality is not anymore connected with women's social 
status.

Besides, in the future society sexuality is not central anymore to women's social identity: their status derives from being humans with rights like men. Thus, Luciente tells Connie, "We couple ... for love, for pleasure, for relief, out of habit, out of curiosity and lust" (Piercy, p. 64). For a while, Connie mistakes Luciente for a man, and thinks that she has been gone under one of those sex-change operations.

Piercy goes further by separating sexuality from production in the future society. Technology is used to emphasize this concept. Babies are grown to birth in brooding machines. Hence, Piercy releases females from the capacity for child bearing in the future society. When it comes to breast-feeding, each child does have three mothers; at least two agree to breast-feed. The male mothers reflect changes signaling the end of gender roles. Women and men all are equal in all things: education, work, sexual expression, and even parenting, as Luciente puts it,

It was part of women's long revolution. When we were breaking all the old hierarchies. Finally, there was the one thing we had to give up too, the only power we ever had, in return for no more power for anyone. The original production: the power to give birth. Cause as long as we were biologically enchained, we'd never be equal. And males never would be humanized to be loving and tender. So, we all become mothers. (Piercy, p. 105)

The strange thing to Connie is that males have breasts and become mothers for children. Both giving birth and breast-feeding are expected from women in Connie' current society. Due to the fact that "in Connie's United States, women, especially poor and marginalized ones, are chained to stereotypes of motherhood and inferiority" (Minico, p. 8), Connie "comes to realize that sacrificing biological gestation [is] indeed necessary to achieve the gender equality" (Kendal, p. 68).

As long as women are equal in the future community with men even in what is expected to be women's duties in the present society, the whole future society, including women, finds that:

Our dignity comes from work. Everyone raises the kids, haven't you noticed? Romance, sex, birth, children-that's what you fasten on. Yet that isn't women's business anymore. It's everybody's. (Piercy, p. 251)

Based on equality, justice, communal respects among all members, such an ideal community exceeds expectations; it becomes a utopia for Connie and her generation. Such a community "provides an alternative to the patterns of Connie's present and the dystopian future" (Seabury, p. 140) of Gildina. Accordingly, Connie does not hesitate to tell Luciente, "I want to be with you." Moreover, her lover from this future society, Bee, points out, "We feel you're family" (Piercy, p. 307).

In general, Piercy critiques her society and presents the values of the present world in her Woman on the Edge of Time. The heroine's social status "enables the author to use [Connie] to expose and denounce the abuses" (Gilarek, p. 224) found in her contemporary society. Colored women suffer twice for they are not white and they are female. They suffer racism and its consequences from the whites, and suffer inferiority, oppression, and aggression from other colored males as well. Connie suffers for being a female; her husband, Eddie treats her badly. Her brother also wants to get rid of her, so he signs her to the mental hospital. She suffers racism and bad treatment from the whites. At last, she is used for the purpose of experiments. It is only her time-travels to the future society that give her the meaning of being associated to someone else. She accepts Luciente's criticism, "If we don't crit you, how will you grow" (Piercy, p. 212). It is the future society where she gains confidence and receives advice. At the end, she decides to poison the doctors' coffee because it is the only convenience for her situation in order to get rid of "the medical staff who embody oppressive power" (Minico, p. 3). Luciente argues,

Power is violence ... You know we kill people who choose twice to hurt others. We don't think it's right to kill them. Only convenient. (Piercy, p. 370)

She has no chance to "breathe the air of freedom" (Piercy, p. 29), but she has a chance to help other patients so that they may survive the insincere treatment Connie herself has been exposed to. By doing so, she can also participate in creating a promising future by getting rid of her oppressors who, if they have a chance, may help in reproducing another boring, hard, and "monitored" future, like that of Gildina; such a future will materialize the continuity of Connie's contemporary oppressing and suppressing society. Indeed, the utopian future functions in more than one way in the novel. First, the heroine finds in this future a dream-like resort to escape the atrocities of her real society. Second, the author utilizes this future to shed light upon and critically addresses urgent social issues like class, gender, and race. Finally, by inventing this future, the author provides her heroine a scope where Connie's human potential is valued and her silenced voice is heard by her friends in this future and 
ultimately by readers of the novel.

\section{References}

Afnan, E. (1996). Chaos and utopia: Social transformation in woman on the edge of time. Extrapolation, 37(4), 330-340. https://doi.org/10.3828/extr.1996.37.4.330

Ashcroft, B. (2007). Critical Utopias. Textual Practice, 21(3), 330-340. https://doi.org/10.1080/09502360701529051

Bakay, G. (2018). Doctor-Patient Relationships in Marge Piercy's Woman on the Edge of Time and Simone de Beauvoir's A Very Easy Death. Advances in Social Sciences Research Journal, 5(9), 332-337. https://doi.org/10.14738/assrj.59.5175

Bammer, A. (1991). Partial Visions: Feminism and Utopianism in the 1970s. New York: Routledge.

Bartkowski, F. (1989). Feminist Utopias. Lincoln: U of Nebraska P.

Bradshaw, R. (2012). Utopia. Nottingham: Five Leaves Publications.

Broad, K. R. (2012). Courting utopia: The romance plot in contemporary utopian fiction (Order No. 3508648). Available from ProQuest Dissertations \& Theses Global. (1018101602). Retrieved from https://search.proquest.com/docview/1018101602?accountid=30641

Gilarek, A. (2012). Marginalization of "the other": Gender discrimination in dystopian visions by feminist science fiction authors. Text Matters, 2(2), 221-238. https://doi.org/10.2478/v10231-012-0066-3

Jameson, F. (2000). Utopia and Failure. Politics and Culture, 2. Retrieved from https://politicsandculture.org/2010/08/10/utopia-and-failure-by-fredric-jameson-2/.

Jones, A. H. Feminist Science Fiction and Medical Ethics: Marge Piercy's Woman on the Edge of Time (pp. 171-183). In Myers.

Kendal, E. (2018). Utopian Literature and Bioethics: Exploring Reproductive Difference and Gender Equality. Literature and Medicine, 36(1), 56-84. https://doi.org/10.1353/lm.2018.0002

Lefanu, S. (1988). Feminism and Science Fiction. Bloomington: Indiana UP.

Makinen, M. (2001). Feminist Popular Fiction. New York: Palgrave. https://doi.org/10.1057/9780230511781

Marcia, B. S. (2001). The monsters we create: Woman on the Edge of Time and Frankenstein. Critique: Studies in Contemporary Fiction, 42(2), 131-143. https://doi.org/10.1080/00111610109601133

Mcbean, S. (2014). Feminism and futurity: Revisiting marge piercy's woman on the edge of time. Feminist Review, (107), 37-56. https://doi.org/10.1057/fr.2014.1

Minico, E. D. (2019). Spatial and psychophysical domination of women in dystopia: Swastika night, woman on the edge of time and the Handmaid's tale. Humanities, 8(1). https://doi.org/10.3390/h8010038

Myers, R. E. (1983). The Intersection of Science Fiction and Philosophy: Critical Studies. Westport: Greenwood Press.

O’Byrne, D. M. (2012). Marge Piercy's Non-Utopian Women on Edge of Time (pp. 75-84). In Bradshaw.

Palumbo, D. (1986). Erotic Universe: Sexuality and Fantastic Literature. New York: Greenwood Press.

Piercy, M. (1976). Woman on the Edge of Time. New York: Fawcett Crest.

Rudy, K. (1997). Ethics, Reproduction, Utopia: Gender and Childbearing in Woman on the Edge of Time and The Left Hand of Darkness. NWSA Journal, 9(1), 22-38. https://doi.org/10.2979/NWS.1997.9.1.22

Seyferth, P. (2018). A Glimpse of Hope at the End of the Dystopian Century: The Utopian Dimension of Critical Dystopias. ILCEA [Online], 30. https://doi.org/10.4000/ilcea.4454

Spector, J. (1986). The Functions of Sexuality in the Science Fiction of Russ, Piercy, and Le Guin (pp. 197-207). In Palumbo.

Sümbül, Y. (2014). Marge piercy's conception of a feminist utopia in woman on the edge of time. Dil Ve Edebiyat Egitimi Dergisi, 2(10), 174-183. Retrieved from https://search.proquest.com/docview/1614637754? accountid=30641

Thibodeau, A. R. (2011). Gender, utopia, and temporality in feminist science fiction: (re)reading classic texts of the past, in the present, and for the future (Order No. 3468311). Available from ProQuest Dissertations \& Theses

Global.

(887712726).

Retrieved

from 
https://search.proquest.com/docview/887712726?accountid=30641

Tyler, B. (2017). Reconceptualizing Feminist Utopias: Marge Piercy's Woman on the Edge of Time and Margaret Drabble's The Millstone. Oregon Undergraduate Research Journal, 11(1). Retrieved from http://www.ourj.uoregon.edu

Wetzel, A. (2014). Alienating punishment: Prisons in science fiction (Order No. 3631993). Available from ProQuest Dissertations \& Theses Global. (1566492985). Retrieved from https://search.proquest.com/docview/1566492985?accountid=30641

Yla-Kapee, A. (2014). Telling Madness: Narrative, Diagnosis Power and Literary Theory. Tempere UP.

\section{Copyrights}

Copyright for this article is retained by the author, with first publication rights granted to the journal.

This is an open-access article distributed under the terms and conditions of the Creative Commons Attribution license (http://creativecommons.org/licenses/by/4.0/). 